\title{
Synthetic Utilization of 2,6-Dioxa-3-azabicycloalkenes toward Cyclic Ethers
}

\author{
Ihl-Young Choi Lee, Jae Hyun Lee, and Hyo Won Lee \\ Kore'a Research Institute of Chemical Technology, Taejeon 305-600, Korea \\ "Department of Chemistry, Chingbuk National University, Cheongiu 361-763. Korea \\ Received December 7, 2001
}

Keywords : Hetero Diels-Alder reactions. Bicyclic heterocycles, Cyclic ethers. Mevalonolactone.

The nitrosoalkenes are very useful synthetic intermediates because of double bond in conjugation with nitroso group.' The [4-2] cycloaddition reaction of vinylnitroso compounds with electron-rich alkenes furnishes 5,6-dihydro-4H-I,2oxazines (1). ${ }^{\mathrm{I}}$ The $\mathrm{N}-\mathrm{O}$ bond of 1,2-oxazines can be reductively cleaved to obtain hydroxyketones, while $\mathrm{C}-\mathrm{O}$ bond of 1,2-oxazines can be cleaved under the acidic or thermal conditions. These reactions have been utilized to prepare pyrroles. ${ }^{2}$ pyrrolidine, ${ }^{3}$ pyridines, ${ }^{4} \gamma$-lactones, ${ }^{5}$ and so on. Herein we would like to report the expansion of $[4+2]$ cycloaddition reaction of vinylnitroso compounds derived from $\alpha$-halooximes or $\alpha, \alpha$-dihalooximes toward the preparation of cyclic ethers via 2,6-dioxa-3-azabicycloalkenes.<smiles>[R]C(=C[N+](=O)[O-])C([R])[R]</smiles>

It has been reported that the hetero Diels-Alder reaction of nitrosoalkenes, generated in situ from $\alpha$-halooximes, with allylic alcohols provides dihydro- $4 H$-oxazinylmethanols. "In our synthetic route, the introduction of a halogen atom at the 4-position of oxazine ring $\mathbf{4 a}$ derived from halooximes $\mathbf{2}$ leads to 2,6-dioxa-3-azabicycloalkenes $\mathbf{5}$ wia intramolecular nucleophilic substitution of a halogen atom by a hydroxy group (Scheme 1). The reductive cleavage at $\mathrm{N}-\mathrm{O}$ bond of the oxazine ring yields cyclic ether 6 .

As a starting material, $\alpha, \alpha$-dihalooximes 2 a were chosen to provide halo-substituted oxazine derivatives 4a. Thus, dihaloketones were treated with hydroxylamine in $\mathrm{MeOH}$ at room temperature for 2-4 days to furnish compounds $\mathbf{2 a}$. Halovinylnitroso compounds generated in situ by the reac-

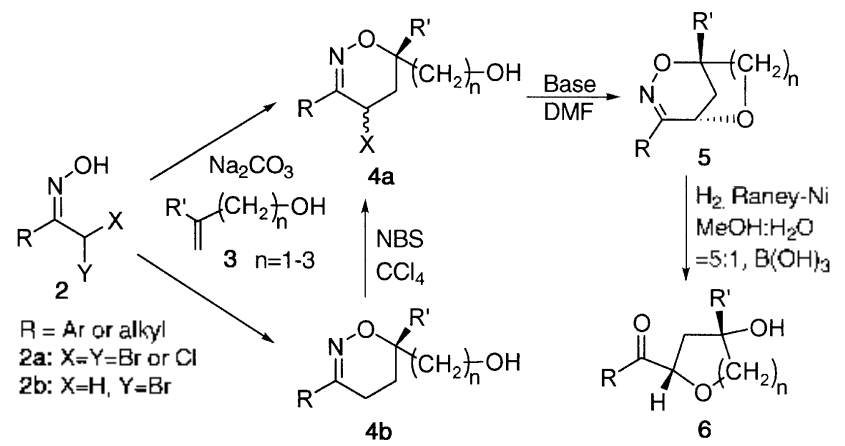

Scheme 1 tion of 2a with $\mathrm{Na}_{2} \mathrm{CO}_{3}$ or $\mathrm{Cs}_{2} \mathrm{CO}_{3}$, underwent [4-2] cycloaddition with allylic alcohols 3 to give isomeric mixtures of 5,6-dihydro-4-halo-1,2-oxazines $4 a$ in 35-94\% yield. Alternatively, slight modification of reaction pathway was adopted as follows. Bromo compounds $\mathbf{4 a}$ were prepared from the bromination of compounds $\mathbf{4 b}$, which was derived from monobromooximes $\mathbf{2 b}$, with NBS. When these oxazines $\mathbf{4 a}$ were treated with a base such as $\mathrm{NaH}$ or $\mathrm{KH}, 1.4-$ disubstituted 2,6-dioxa-3-azabicyclo[3.n-1.1]3-alkene $\mathbf{5}$ were obtained as only rans isomers in $73-92 \%$ yield.

The reductive cleavage of $\mathrm{N}-\mathrm{O}$ bond of bicyclic oxazines 5 with Raney nickel (methanol: $\mathrm{H}_{2} \mathrm{O}-5:$ I) gave stereoselectively acylated cyclic ethers 6 in good yield. 'The results were shown in Table 1 . In the case of entries 2 and 6.

Table 1. Reductive Cleavage of Bicy clic Oxazines

(n)


where $\mathrm{R}$ is $t$-butyl, we could not directly prepare $4 \mathrm{a}$. Thus, bromination of $\mathbf{4 b}$ was utilized.

As an effort to expand the synthetic application of this reaction, pyranyl product 7 from entry 3 was subjected to Baeyer-Villiger oxidation to obtain compound $\mathbf{8}$ in $82 \%$ yield. Subsequent hydrolysis of ester group and oxidation of lactol yielded mevalonolactone $9 .^{8}$<smiles>CCCCCCCCCCCCCC(=O)c1ccccc1</smiles><smiles>CC(=O)OCC(=O)OOC1CCC(O)(O)CC1</smiles><smiles>CC1(O)CCOC(=O)C1</smiles>

Currently we are investigating our method for the synthesis of other heterocycles 10 with heteroatoms such as nitrogen and sulfur atoms.<smiles>[Y][C@H]1CCCCC([R])(O)C1</smiles>

10

Acknowledgment. We are grateful to the Korean Ministry of Science and Technology for financial support (KG-9706).

\section{References}

1. (a) Gallos. I. K: Sarli. V. C.: Kottis. T. V.: Coutouli-Argyropou- lou. E. Tetruhedron Lett. 2000. H. 4819-4822. (b) Tahdi. A.: Titouani, S. I., Soufiaoui. M. Tetrahedron 1998. 5t. 65-70. (c)

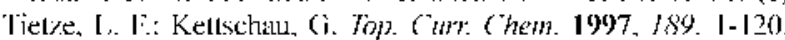
(d) Streith. J.: Deloin. A. Sinthe'sis 1994. 1107-1117. (e) Yimmer. R.: Collas. M.: Roth. M.: Reissig. H. L. Liebigs Ann (hem. 1992. 709-714. (f) Arnold. T.: Orschel. B.: Reissig. H.-U. Angew. Chem. Hh. Ed. Engl. 1992. 31. 1033-1035. (g) Hippeli. C.: Reissig. I1. U. Liebigs thm Chem. 1990. 217-226. (h) Arnold. T.: Reissig. Il. 1: Sintett 1990, 514-516. (i) Boger. D. 1.: Weinreh. S. M. Hetero Diels-Alder Wethodology in Orgenic Sinthess: Acadernic Press: New York. 1987: pp 71-93. (j) Cilchrist. I: L. Chem. Soc. Rev 1983. 12. 53-73. (k) Keck. G. E.: Wobb. R. R.: Yates. I. B. Tetrahedron 1981. 37. 4007-4016. (I) Faragher. R.: Gilchrist. T. I. J. (hen. Soc. Perkin Troms. / 1979. 249-257.

2. (a) Oppolyer. W.: Bättig. K.: H ludlicky. K. Tetroh'dron 1981. 37. 4359-4364. (b) Nakauishii. S.: Shirai. Y.: Takahashi. K.: O1suji. Y. Chem. Lett. 1981. 869-872.

3. Angermann. J.: Homann. K.: Reissig. H.-U.: Zimmer. R. Sintent 1905. 1014-1016.

4. Faragher, R.: (jilchrist. T. I... ('hem. Soc., Perkin Thans. / 1979. $258-262$.

5. Gilchrist. I. L.: Rotherts. I. (i. I. Chem. Soc., Chem. Commun. 1979. $1089-1090$.

6. Stevensen. T. M.: Patel. K. M.: Crouse. B. A.: Folgar. M. P.: Hutchison. (.. D.: Pine. K. K. Simhesis and Chemistry of dgrochemictls: l3aker. D. R.. lenyes. J. (i. laasarah. (j. S.. Fds.: ACS Symposium Series 584: American Chemical Sociely: Washington DC. 1995: vol. IV. pp 197-205.

7. Fiscra. L.: Goljcr. I.: Jaroskora. L. Collect. Caech. Chem. Commtm. 1988. 53.1753-1760.

8. (a) Takiano. S.: Morimoto. M.: Ogasawara. K. J. (hem. Soc. (hem. (ommun 1984, 8283. (b) Bolitt. V.: Mioskowski, (...) Org. (hem. 1991, 56. 4238-4240. 